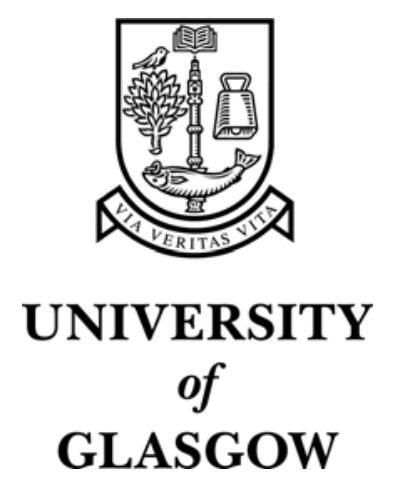

Clayton, P. Religion, ethnicity and colonialism as explanations of the Northern Ireland conflict. In Miller, D. (Eds) Rethinking Northern Ireland: culture, ideology and colonialism, Chap 2, pages pp. 40-54. First published in London by Longman: Longman (1998)

http://eprints.gla.ac.uk/archive/2784/ 


\section{Religion, ethnicity and colonialism as explanations of the Northern Ireland conflict P M Clayton}

\section{Introduction}

Northern Ireland is not only a problem because of the conflict and lack of political progress; it is also a problem about which theoretical questions can be asked and for which an explanatory framework can be sought. People have accordingly asked questions, and from a wide range of disciplines, including economics, history, political science, psychology, social psychology, social anthropology and sociology. Each of these, furthermore, incorporates different tendencies and schools of thought. So there is a wide range of explanations on offer (for works reviewing these see Lijphard 1975, Martin 1982 and Whyte 1990). What these largely have in common is that they are very different from popular notions that the conflict is 'religious', 'tribal', mere gang-warfare driven by 'hard men', or in other ways anachronistic, mindless or merely reprehensible.

Given the well-known division between 'Protestants' and 'Catholics' (terms which will be retained here largely because they are widely used both within and beyond Northern Ireland), the idea that the conflict is religious deserves careful consideration. It is, however, very much a minority view among sociologists, and indeed participants, that the religious divide is both the cause of the conflict and the fount from which Protestant fears spring. The other two explanations examined here propose that the divisions are founded on, respectively, settler colonial history and ethnic difference. These are not mutually exclusive.

\section{Northern Ireland as a religious conflict}

A term frequently used in the Northern Ireland context is 'sectarianism', used to mean mutual dislike between Protestant and Catholics. That the hostility in the religious sphere, where it exists, is mutual is not in doubt; but the term suffers from the handicap that the inferior social, economic and political state of the members of one sect, Catholics, is not obvious from the term. 
Nevertheless it is not surprising that the ethnic division most frequently highlighted both in the academic literature, as well as in the media and 'commonsense' perceptions outside Northern Ireland, is between actors in their roles as Catholics and Protestants. Aughey's (1989:4) observation that Northern Ireland is a society ‘permeated with religious imagery and sectarianism’ may app.ear extreme; but the very frequency of the labels 'Protestant' and 'Catholic' used by insiders themselves points to the importance of religion, which is indeed one of the features distinguishing the region from the rest of the United Kingdom. Virtually everybody if pressed identifies him/herself with a religious grouping and identifies other people in the same way (Rose 1971:248; Whyte 1990:20). Much of the academic literature takes religious affiliation as a line of cleavage for the study of disadvantage in Northern Ireland (for example, Aunger 1975; Boyle 1977; Compton 1976; Osborne 1981) or attitudes and value systems (for example, McKernan and Russell 1980; Rose 1968; Stringer 1991). Even public housing policy is constrained by the religious divide (Singleton 1982:78-81), and a majority of people in urban areas live in towns that have had high rates of segregation since at least 1911 (Poole 1982:292, 300).

The sociologist best-known for propounding that Northern Ireland's conflict is religious is Steve Bruce, a sociologist of religion. In a debate held at the Queen's University of Belfast following the publication of a number of books on Northern Ireland, including his ‘God Save Ulster!' (1986), he declared, 'The religious division is the cause of the conflict': Catholicism and Protestantism are essentially opp.ositional in nature and if native and settler had shared the same religion, marriage would have eroded the ethnic boundaries.

There is certainly evidence for this assertion. Church attendance figures are very high by international standards: about 90 per cent of Catholics claim to go to church at least once a week and 50-60 per cent of Protestants at least once a month. Churches also have a wide range of ancillary social functions (Whyte 1990:26-7). The Orange Order, open to Protestants of all denominations but closed to Catholics, and influential in Unionist politics particularly in the period of Unionist government, has often insisted that it is a purely or primarily religious organisation (see, inter alia, Orange Institution 1885, 1891 [proceedings of 1.6.1881], 1902, 1916, 1963; ‘Veritas’ 1813). The best 
indicator for voting behaviour in respect to nationalist and unionist parties is religious denomination (McAllister 1983:194); and Northern Ireland is remarkable both in the close correlation between religion and voting and in the stability of this pattern over time (Whyte 1990:72). Intermarriage across the Protestant-Catholic divide, discouraged from the first by all the churches, is still extremely low today; Rose (1971:329, 341) found that only four per cent married across the religious lines and a number of later studies supp.ort this low level (Buckley 1982:64; McFarlane and Graham 1979:194) although the incidence of intermarriage varies from place to place (Whyte 1990:41). This degree of endogamy arises partly out from the particularly hostile attitude of the Roman Catholic church to marriage with non-Catholics and partly from the limited chance to meet people of the 'opposing' religion, due in part to residential segregation where it exists but mainly to educational segregation. Since nearly all schools are either state-supp.orted (with Protestant clergymen on the board of governors) or Catholic, the majority of people (over 95 per cent of Catholics and nearly all Protestants) receive their primary and the bulk of their secondary education at unidenominational schools or schools with a very small percentage of 'the other sort' (Whyte 1990:43).

Yet this picture of religious influence and two-fold division in Northern Ireland needs qualifying. The influence of the churches is unevenly distributed, probably at its lowest among working-class Belfast Protestants; the leaders of the Roman Catholic, Presbyterian, Episcopalian and Methodist churches meet regularly; the churches are involved in a high proportion of the peace and reconciliation projects; there are around fifty different and in some cases mutually hostile Protestant denominations so Protestants do not form a monolithic group; and the churches can be divided into fundamentalist and liberal, with different attitudes to Roman Catholicism (Whyte 1990:27-30). Furthermore Bell (1986:13) states that religious observance among Protestants is in decline, particularly in the 17-30 age group.

The Orange Order's claim to be purely religious is not accepted by most academic observers (for example, Roberts 1971:278) or borne out by its history (see for example Boyle 1962; Gibbon 1972; Patterson 1980), and is belied in two ways. Firstly its assertion that it stands for civil as well as religious liberties in itself contradicts its claim, even though it is argued that the two are inextricable 
in Protestantism. More important, however, are its interventions in politics both as an organisation (see, for example, the monthly newspaper the Orange Standard) and through individual members' involvement. A survey of Orange literature, including that of the Independent Orange Order, also reveals a political mission behind its protestations of political innocence (see ‘An Orangeman' 1799; Crawford 1904; Cupp.les 1799:8-9; Dewar 1958:7, 22; Long 1972:, 1978:2-12; Niven 1899:25; Orange Institution 1813, December 1884, December 1885, June 1886, December 1889, 1891 and the proceedings of 7-8/12/1881, 4/11/1882; Rogers 1881; Smyth 1972).

It would probably be more app.osite, in the light of Horowitz's study (1977:9) of the relationship of culture to ethnic movements, to see the origins of the Orange Order in the need to maintain or restructure boundaries, and since ‘boundaries must be underpinned by a suitable mythological app.aratus', a cultural movement is a necessary precursor of political action. Its strength is another consideration: only about a third of Protestant men are members; its strength is unevenly distributed, app.earing to be greatest in rural border areas (Whyte 1990:31-2); and some Protestants are very hostile towards it (Patterson 1982:26).

As for the influence of religion on voting, although it is true that Protestants are particularly cohesive in their voting behaviour (Whyte 1990:76), and they supp.ort in overwhelming numbers parties which favour the link with Britain, doctrinal differences in themselves have little impact on political attitudes (Lijphart 1975:87; McAllister 1982:342). There is one exception, the case of the fundamentalist Protestantism from which Todd (1987:3) sees loyalism deriving its power. The best example of this is the kernel of Paisley's Free Presbyterian Church at the centre of the loyalist DUP. Even here the picture is complicated. A survey of Belfast Protestants by Boal and Livingstone (Whyte 1990:30) published in 1986 indicates that fundamentalists are a minority, albeit a large one, in Northern Ireland and that the UUP draws supp.ort from both fundamentalists and liberals whereas the DUP is more likely to be favoured by fundamentalists. On the other hand, much of the DUP's voting strength comes from the urban working-class with no formal religious affiliations; and moderate unionists such as Todd's Ulster British tend to dislike this brand of sectarian politics, seeing their 
unionism as a product of their adherence to the progressive, liberal, tolerant and democratic 'British' ideals (Todd 1987:13).

Wright (1973:233) defines the majority of loyalists as anti-Catholic and especially anti-Irish rather than positively Protestant. Other observers too see the conflict as politico-religious. Rose (1971:3001, 397-407), finding religion and nationality the most important indicators of political attitudes, puts forward the basic thesis that the reason the conflict is so intractable becauseit is about religion and nationality which, unlike material benefits, are non-bargainable. Easthope (1976:450) offers a different perspective in understanding the conflict as a religious war in the sense that 'the 'churches' in conflict are Loyalism and Republicanism, each with their own rituals, symbols and traditions'.

Despite the unusually prominent role of religion in Northern Ireland, actual doctrinal differences are hardly ever seen as fundamental to the conflict (Brewer 1992:357). Bruce himself adds to religious conflict ‘differences in language, ethnic identity and economic circumstances’ as basic divisions which meant that 'the formulation of political interests would deepen and reinforce the religious divisions' (1986:247-8). He also supp.oses that, although the Northern Ireland conflict is religious as far as the ideology of evangelical Protestants is concerned, secular Unionists are driven to vote for parties like the DUP because modern secular Britain can no longer be relied on to maintain the constitutional link (1986:137). A joint publication, ‘No Surrender!’ (Wallis, Bruce and Taylor 1986) makes it quite clear that the authors follow Durkheim in seeing religion as a sign, a symbol of something else. For Durkheim, religion was a symbol of society, and its rituals functioned to maintain social solidarity; in worshipp.ing a totem or a god, people were in a sense worshipp.ing the ideal of society. Society was seen in very positive terms as a defence against the anarchy of individual desires. For Wallis et al, on the other hand, religion is a sign of identity in a situation of inter-group conflict.

Bruce qualified his earlier assertion thus:

... for Protestants, the Northern Ireland conflict is a religious conflict ... the only strong ideology which can provide a basis for unionism is evangelical Protestantism. Thus, at least for one side of the battle, the Northern Ireland conflict is, to a far greater extent than most of 
us with our liberal Christianity or our atheism have been prepared to recognise, a religious conflict (Bruce 1987).

The use of religion for political purposes does not, however, make it a religious conflict in the sense of a conflict caused by religion or informed by purely religious values. It is open to question whether there has ever been such a conflict. Religion can be seen as intimately linked to power. It is very clear from the history of the early Christian church, for example, that power-struggles among true believers were endemic almost from the start, with fragmentation along the fault-lines of ethnicity, wealth, status, gender and so on. This is only one example. Another is the split in Islam between Sunni and Shia, which in its origins was social, political and factional, anything but doctrinal.

Similarly in the case of Northern Ireland, religion is frequently viewed in academic writings as intrinsically political rather than spiritual. For example, Namier (Wallerstein 1974:207) dismissed religion as 'a sixteenth century word for nationalism'. Lichtheim (1971:34) treats it as a legitimating ideology for imperial expansion, pioneered in Ireland under Cromwell, whose policies led to Catholicism becoming a major element of Irish identity (Smith 1986:245). Cahill (1970:236) sees it partly as a disguise for economic motives in the anti-popery campaigns with which Irish Protestants greeted the 1829 Catholic Emancipation Act and O’Connell's 1834 civil rights programme. Similarly, Anderson (1988:138) holds that, although unionist ideology from 1886 onwards was often expressed in religious terms, the opp.osition to home rule was essentially secular, and Savage (1960:196) points to the use that the Ulster Loyalist Anti-Repeal Union made of religion, as propaganda to be used whenever speakers in Great Britain considered it effective. Finally, the political significance of the religious divide has been seen as situational; comparison with societies similarly divided in religious terms, such as the Netherlands, Belgium and Switzerland, suggests that religion is not an independent variable, and that causal factors for conflict on the Northern Ireland scale must be sought elsewhere (Brady 1978:97-8; Smith 1981:51; Whyte 1990:72). 


\section{History}

Undoubtedly politico-religious factors were important in the relationship between England and Ireland. In the twelfth century, the first Norman incursions into Ireland were authorised by the Pope. This was Adrian IV, the only Englishman ever to attain the Holy See - surely not a coincidence. At the time Roman Catholicism was the religion in Western Europe, but Irish Catholicism retained certain practices which were sufficiently different from English/Norman Catholic ones to allow them to be castigated as essentially non-Catholic, and even pagan (Canny 1973). It takes only a small degree of difference for a group inferior in power to be stigmatised. The magnification of differences and the focus on these differences to the exclusion of similarities are normal features of derogatory discrimination in many kinds of inter-group relations. So even when the would-be conquerors and their intended victims were of the same religion, religious differences were used to legitimate aggression.

At the time of the more successful conquest of Ireland by the English Elizabeth I in the sixteenth century, England had left the Roman Catholic church whereas Ireland was still Catholic. This is not to say, however, that England had become 'Protestant' through doctrinal disagreements. From the time of the Plantagenets, England had refused to obey the Papal will where there was a conflict of interest with English national and territorial aspirations. Its great distance from Rome and its strong defensive position as an island guarded by unpredictable weather facilitated these tendencies in English monarchs to disobey the Pope when this best suited their interests. The best-known example is Henry II’s defiance, culminating in the assassination of Thomas à Becket. The official split with the Roman Catholic church, as is well known, came finally with Henry VIII, most notorious for his six marriages, only three (or perhaps four, since the marriage with Anne of Cleves was not consummated) of which were legal under Church law. The subsequent seizure of monastic lands and church properties was undoubtedly more than a happ.y unsought bonus for the royal treasury: several years before Henry sought his divorce, all monasteries with fewer than seven inmates had been supp.ressed and their revenues expropriated to provide revenue for him to pursue his foreign policy. Henry remained Catholic in all but one respect: he proclaimed that he, not the Pope, was head of the church in 
England; otherwise he tried to live up to the title of 'Defender of the Faith' bestowed on him by Pope Leo X for his former reply to Luther defending all Catholic doctrines. It was only after Henry’s death and the accession of Edward VI that the drift to Lutheran Protestantism began. Even so, despite additions such as the Thirty-Nine Articles and Book of Common Prayer under Elizabeth, today's Anglican and Catholic services are almost identical.

The original break with the Catholic Church, then, was inherently political, not doctrinal; it was only under Elizabeth I that English Protestantism and English nationalism merged. Even then, in the face of the Spanish Armada - whose stated purpose was to restore the Catholic faith in England but whose real object was to put a stop to English piracy and trouble-making in the Spanish Netherlands Protestants and Catholics alike were enrolled for defence of the realm.

What is also relevant to understanding the new incursions into Ireland is that England was moving recognisably towards capitalism. Capitalism and Protestantism, according to Weber (1930), have an elective affinity; but Weber was talking about Calvinism, and this was detested by English rulers until the time of Cromwell. Indeed, the origins of capitalism can be traced much further back, at least to the twelfth century (MacFarlane 1978). So England's move towards capitalist values and practices owed nothing to Calvinism; but the sixteenth century conquest of Ireland can be seen as driven partially by the flowering of capitalism with its insistence on the private ownership of property (Crotty 1986).

At the same time, English foreign policy increasingly came into conflict with the Catholic nations of Europe, and her back doorstep was Catholic Ireland, which could be expected to put out the welcome mat for enemies of England. So in the European context, this new attempt at controlling Ireland made political sense. Religion was a factor, but it was a political factor. And one way, perhaps, in which Ireland could be more successfully controlled, was through what is called 'plantation' - which means the establishment of colonies of settlers, in the Irish case in Munster, the southernmost part of Ireland, and Ulster.

The more popular accounts of Ulster history and mythology give the impression that all the planted settlers were Scottish Presbyterians, that is, Calvinists, Dissenters - true Protestants in that they challenged many of the doctrines and practices of the Catholic Church (and also the Anglican 
Church) as well as its temporal authority. This is by no means accurate. The 'undertakers', who were granted lands to which they were to recruit settlers, were members of the Anglican establishment. Under Elizabeth, plantation was an English venture, and the attempt was made to attract English settlers. These, however, could not be recruited in sufficient numbers for such a distant and unknown region, whereas Scots, particularly from Galloway, were much more accustomed to travelling over to Ulster. The two regions, a mere nineteen miles apart at the narrowest, had exchanged populations over thousands of years, long before Christianity, or capitalism, or nation-states. In more recent times, too, Scottish Presbyterians had migrated to Ulster and were living peacefully among the 'native’ Irish. Dissenters, however, were frowned upon, particularly by James VI of Scotland and I of England, who continued Elizabeth’s Irish policies, and they formed no part of the official Plantation. Furthermore, like Catholics, they became subject to various legal disabilities, less severe than those of Catholics but strong enough to drive many Presbyterians onward from Ulster to America in search of religious liberty and freedom to perform civic duties. So certainly the official purpose was not to populate Ulster with Scottish Presbyterians, and the counties where today Presbyterians are most numerous, Antrim and Down in Northern Ireland, did not form part of the Plantation but were settled autonomously by individuals and families both before, during and after the Plantation. These, contrary to the myth of Ulster as a 'desert' made to bloom by Anglo-Scots husbandry (Portadown News, editorial, 10.10.69), were attracted by Ulster’s fertility and the prospect of relative prosperity (Bardon 1992; Robinson 1982).

The six Plantation counties which comprised the official English garrison, Derry, Donegal, Tyrone, Armagh, Fermanagh and Cavan, even today count a predominance of Church of Ireland (that is, Anglican) members among their Protestant populations, for the official settlers were English, and later and more successfully, Scottish episcopalians. According to Lecky (1916), the 1641 rising by the Catholic Irish was aimed at the official settlers and largely spared Presbyterians, notwithstanding the fact that doctrinally Presbyterianism stands opp.osed to Catholicism far more firmly than Anglicanism. And as every Irish republican knows, the 1798 attempt to oust the British from Ireland was not only supp.orted by some Presbyterians but was also dominated by the Presbyterian United 
Irishmen. It was only in the nineteenth century that Presbyterians, Anglicans and smaller sects came together to form 'the Protestant people' in response to the growth of Irish nationalism and the threat that the relatively privileged Irish Protestants would become a powerless minority in a semiindependent Ireland. Doctrinal differences among Protestants continued to matter even when politically they were more-or-less unified, and even in the early twentieth century, 'sectarianism' referred to disputes between the Church of Ireland and the Irish Presbyterian Church.

Although a significant feature of the Catholic majority in Ireland is precisely that it is Catholic, and various 'No Popery'campaigns addressed the fears of many Protestants who had a horror of being 'ruled by' the Pope, this needs to be set in context. Irish Catholics were not merely members of a different Christian sect, they were also a colonised people, a conquered people, a people who had been inferiorised from the twelfth century onwards. They had been subject to more disabilities than Irish Dissenters and they had been unrepresented in the short-lived Irish Parliament which was abolished by the 1800 Act of Union. In short, they had experienced different and inferior treatment from Protestants and had been powerless, so they had much to avenge. But their only strength had been numerical and until the successive extensions of the male franchise throughout the nineteenth century, culminating in the 1884 Third Reform Act, this strength was of little use, except to British Army recruiting officers. The superior firepower of the British Army made it more profitable for Irishmen to join it than to fight it, as many had found to their cost over the centuries, and the Irish of all sects, along with the Scots, formed a disproportionate number of fighting men in the imperial armies, putting Irish Catholics in the curious position of being both imperialists and 'imperialised'. The dangers of training Irish Catholics in British Army techniques may, however, partly explain the fall in this proportion as the nineteenth century progressed (Kiernan 1982). In any case, Catholics became an electoral majority in Ireland and an increasingly worrying situation for Protestants became a critical one.

This is not to say that religious differences are of no consequence at all. Of course they are, and some individuals hold the opp.osing religion in sincere abhorrence. But if there had been no religious differences between the Irish and the English who expropriated their lands and subsequently settlers 
under English protection, some other cultural marker to distinguish between coloniser and colonised would undoubtedly have been sought and found, such as language, history, lifestyle and so on, just as myths had to be invented to mark out assimilated Jewish German from 'real' Germans. The Irish from

the sixteenth century onward, however, were kind enough to retain their Catholic faith, thus obviating the necessity for too much strenuous myth-making.

One result of the doctrinal difference is that much of the discourse is formed by biblical language, by ideas about the 'Church of Rome' and its alleged effect on its followers, and so on. For example, there was a reference to 'the SDLP hierarchy', in a newspaper which purports to see the SDLP as a respectable constitutional party but wishes to remind its readers that it is a Catholic party whose members defer to the more-frequently mentioned ‘Roman Catholic hierarchy’ (Belfast Telegraph, editorial, 24.11.94). Lying behind this reminder, however, is the widespread feeling that the SDLP has more credibility with the British and Irish governments than do the unionist parties - in other words, the real issues are power and influence, not doctrine.

\section{The colonial background}

With a few exceptions, British imperial theorists have paid little attention to Ireland, which is curious considering that it was Britain's oldest and longest-held colony; and the few who do largely ignore the large settler minority in the north and the effects of colonisation on the Catholic Irish. Similarly, in British accounts of settler-metropolis relations the Irish Protestant resistance to Home Rule is rarely mentioned. Both marxists and republicans have focused, though for different reasons, on imperialism as the cause of Northern Ireland's ills; but they have tended to minimise the role of settlers, or to believe that once Protestants recover from their 'false consciousness' of having different interests from Catholics, a settlement will be possible. Protestants themselves have ceased to proclaim their pride in their settler origins (Jackson 1989), which is not surprising since the fate of most settlers in the twentieth century has been dispossession. More regrettably, few writers on Northern Ireland have accepted that the settler colonial origins of the six counties still play an important part in the 
explanation of the current stalemate (for useful expositions of some who do hold this view see Clayton 1996, Lustick 1985, MacDonald 1986, Moore 1972, O’Dowd 1990, Weitzer 1990).

Yet Ireland's history has been colonial since the reign of Elizabeth I of England and the Plantation consisted in the brutal seizure for Protestant settlement of large tracts of land, and the removal of Irish inhabitants. This was justified in terms familiar in similar actions in East and Southern Africa: the 'natives' were pagan, culturally inferior and in need of 'civilising'. Since they continued to outnumber the settlers, Ireland was a mixed colony and there was always a danger of 'native trouble'; but the closeness of Ireland to England facilitated rapid retribution, which enabled the settlers to flourish. The Treaty of Limerick which ended the conflict brought about by the replacement of James II of England by William of Orange asserted Ireland's colonial status and severely restricted Catholics' civil rights (Wallerstein 1980). The 1798 Rising led to a change of status. The Protestant parliament was abolished and Ireland was brought under direct metropolitan control through integration into the realm of the United Kingdom. This was soon followed by Catholic emancipation and successive extensions of the franchise, until the 1884 Reform Act resulted in Irish Nationalists sitting in the British House of Commons.

All reforms which attempted to give Catholics equality of status and treatment were met with virulent opp.osition from the Irish aristocracy and the Orange Order, particularly in Ulster (Gailey 1987). This opp.osition seemed doomed to failure, however, by the time of the 1912 Home Rule Bill, when the Liberal, Labour and Irish Nationalist parties together had a majority in the House of Commons. Only illegal resistance could defeat the measure and this Irish Unionists determined to do by whatever means necessary. Led by Carson, they formed the illegal Ulster Volunteer Force, smuggled in arms and formed a provisional government. They were supp.orted by all the major Protestant churches and huge numbers of Ulster Protestants signed a Solemn Oath and Covenant against Home Rule for Ireland. The Bill became law in 1914 but the intervention of the 1914-18 war, the Easter Rising of 1916 and British government timidity and ambivalence resulted in six counties of Ulster being excluded from the eventual Free State of Ireland (cf O’Dowd on the Border Commission in this volume). 
Unionists had been debating since at least 1912 how much of the settlement could be 'saved' for Protestants. The border was finally settled so as to leave a remnant where Protestants outnumbered Catholics by two to one, though they held a clear majority in only three counties and Derry was a Catholic city. The British government declined to continue ruling any part of Ireland directly, and separate parliaments were set up in Belfast and Dublin, though legally the Northern Ireland Parliament was subordinate to Westminster (where Northern Ireland voters were also represented). Northern Protestants now effectively had their own settler state; their illegal armed forces were allowed to become a 'special constabulary' and draconian security legislation was enacted, which remained in place when the IRA threat ended in 1922; thousands of Catholics had been expelled from their homes and jobs; and the 1922 Conservative Government established the convention that Northern Ireland's domestic affairs could not be discussed at Westminster, although Britain paid for Northern Ireland's 'security' forces and allowed the Stormont government the use of British troops as requested (Farrell 1983).

The Free State, later Republic, of Ireland was economically and militarily weak but it posed a threat in providing an 'ideological homeland' for the North's disaffected Catholics. The granting of residence permits for southerners to do war work in Northern Ireland raised the spectre of Protestants being outnumbered and ultimately voted out of the United Kingdom and the advent of a Labour government in 1945 increased such fears, leading to a campaign for dominion status.

The 1949 Ireland Act allayed these fears for the time being; but another Labour government, in 1969, ended the policy of non-interference when television showed the world the violence committed against the Northern Ireland Civil Rights Association by Protestants and the police, and by 1972 the ‘settler state’ was no more. Westminster had now taken over decision-making in security policy and suspended the Northern parliament. Since then successive British governments have been trying, with varying degrees of commitment but without lasting success, to create an internal settlement through institutions in which Protestants would share power with 'moderate' Catholics, that is, those willing to accept a six-county solution, at least for the time being. All such attempts have foundered on the resistance of Protestants, from non-cooperation to violence, most notably when the British have 
officially involved the Irish government. Westminster rule has been in place since 1972, a situation which few openly favour and which has not ended the violent conflict.

\section{Northern Ireland as a settler society}

Those who have argued against the settler thesis (for example, Aughey 1989, 1990; Buchanan 1988; McCartney 1985; Walker 1990) make a number of points: the Plantation was a long time ago, Ireland ceased to be a colony in 1800, Northern Ireland has a majority of Protestants, it has been an integral part of the United Kingdom at least since 1972 and for all these (and other) reasons there is no reason for Protestants and Catholics to continue to be divided, they should forget the past and look to a peaceful friendly future together. History, then, 'begins' whenever it is convenient for the particular theorist.

If only it were that simple ... The settler mentality has proved extremely durable, for Northern Ireland retains the key elements of a settler society even though the settler state has been replaced by what many Protestants themselves feel is ‘colonial rule'. Protestants and Catholics are still seen as distinct groups and their political interests opp.osed. Non-sectarian political parties attract overall a small minority of votes. Many Protestants still see Catholics as a threat and the majority of Catholics vote for parties aspiring to an all-Ireland state. The security app.aratus is still seen by many Protestants as more important than 'talking to the enemy'. There is still an economic gap which disfavours Catholics. There are undoubtedly important elements of a common culture, but this is normal in settler societies.

Each settler colonial situation has its unique features. Not least among these is that 'settlers' and 'natives’ in Northern Ireland are indistinguishable in app.earance (see McVeigh, this volume). Nevertheless the similarities are more remarkable than the differences. For example, both twentieth century Northern Protestants and white settlers in Rhodesia have claimed that the 'natives' had no history worthy of the name before the settlement; 'native' protests and insurrections were proof not of genuine grievances but of the need to maintain control over them; the 'natives' had certain immutable 
characteristics which made them unfit to rule themselves and certainly precluded them from wielding power over settlers.

Other basic features of settler societies, theorised notably by Hartz (1964), Fanon $(1965,1967)$ and Memmi (1990), have been observed by a wide range of writers. All of these have been documented for the settler societies of Rhodesia, Kenya, South Africa, Algeria and Israel and some telling comparisons have been made between Northern Ireland and each of these countries (see, for example, Crotty 1986; Guelke 1988; Lustick 1985; MacDonald 1986; O’Dowd 1990; Schutz and Scott 1975; Weitzer 1990). These include the 'fixity’ of the basic ideology, which arises from the need to defend interests; the fear and hatred of change; and the intransigence of fixed positions. The peculiarity of class relations in Northern Ireland is normal in settler societies, where typically a range of classes emerges among settlers themselves. Instead of class conflict, intra-class solidarity is the norm and this is reinforced by frequent app.eals to unity. Socialist parties make little headway in the face of the overriding determination to retain settler power. Those who advocate friendship or equality for the powerless group are labelled 'traitors'. 'Democracy' is proclaimed as a settler value and the settler society is indeed more egalitarian than metropolitan society; but this democracy is partial and attempts to exclude the 'natives'. In the case of Northern Ireland, the very boundaries were chosen to ensure a permanent Protestant majority; minority rights were not guaranteed and there was no possibility of alternation in office.

A less well-known feature of settler societies, with parallels in Northern Ireland, is that settler attitudes towards their territory range from a fanatical and if necessary murderous resolve to retain it to an equally fierce resolve to work towards ending settler power by whatever means, including terrorism, they think necessary (Fanon 1965). The presence of a minority of both moderates, ready to accommodate the 'natives' and share at least some resources, and dissidents, ready to join the 'natives' in their campaign for an end to settler domination, is well attested and certainly app.lies to Northern Ireland. To label people 'settlers' is to describe their structural situation, not to stigmatise members of the group. 


\section{Ethnicity as an explanation of the Northern Ireland problem}

What explanations in terms of both ethnic and settler colonial divisions have in common is that they conceptualise religion as a sign of identity in a situation of inter-group conflict. Weber's definition of ethnic groups as 'those human groups that entertain a subjective belief in their common descent because of similarities of physical type or customs or both or because of memories of colonisation and migration’ seems peculiarly apt (Sinnott and Davis 1981:398). It is in the roots of that inter-group conflict that disagreement arises.

In the literature on Northern Ireland 'ethnicity' is a common term used to describe ProtestantCatholic difference. To speak simply of ethnic groups implies nothing about inequalities in power, but this danger is avoided by placing ethnicity within the context of a plural society, where groups attempt to retain their separateness and where one or more groups are subordinate to the most powerful group. One of the most important, albeit flawed, works on Northern Ireland as a plural society is Wright's Northern Ireland: a comparative analysis (1987). Wright's personal concerns included the ending of the violence and supp.ort for the Anglo-Irish Agreement, so he underplays Ireland's colonial history in an attempt to delegitimise violence. Hence he argues that Northern Ireland is an 'ethnic frontier' rather than a settlement colony, on the grounds that it is close to the metropolis - even though he describes it in terms which app.ly equally to settlement colonies, admits that it betrays the ideological features of a settlement colony such as Algeria and cites Fanon on 'native'-settler force relationships in supp.ort of his explanation of the violence. In a later paper (1990) he makes the basis of his objection clearer: taking 1921 as his starting-point, he states without satisfactory explanation that 'their numbers are part of the reason why they are less like settlers than were the colons of Algeria', and 'leaving aside all moral questions' he stresses that the large number of unionists means that 'to impose upon the settler-descendants the choice between being Algerian/Irish or emigrating to France/Britain would involve a qualitatively higher level of coercion by the metropolitan government in the Northern Ireland case than in Algeria' (p. 4). The moral issue is also sidelined in his 1987 work, where, admitting that it is not 'necessarily out of place' to app.ly through ‘rationalistic understanding’ concepts such as ““colonialism”, “racism”, “fascism”, “self- 
determination of nations"', nevertheless to do so is to 'place a moral barrier between themselves and whatever people they find guilty of the "problem"' and fall prey to 'the romantic illusion that divides the world into guilty and innocent parties’ (ibid. 1987:xii-xiii). In other words, he implies that both reason and ethics should be excluded from social science. This cultural relativism has its strengths, in its empathic app.roach and attempt to avoid ethnocentrism; but there is always a danger, exemplified by the 'ethnic' explanation, of marginalising the disadvantage suffered by relatively powerless groups in favour of an ultimately doomed attempt at 'value-neutrality'.

\section{Racism and 'race'}

There is a tendency in the literature on Northern Ireland to consign racial stereotyping of Catholics to pre-partition days. Symptomatic of this is Rex's attempt (1986) to reverse his earlier definition of race relations. This had seemed to include Protestant-Catholic relations in Northern Ireland 'which is a somewhat abnormal usage ... it seemed misleading to suggest that a situation of cultural and religious conflict, albeit with political overtones, like that in Northern Ireland, should be called a race relations situation’ (pp. 20, 36). Despite acknowledging the alleged genetic basis of both racist and ethnocentric attitudes ( $\mathrm{p}$ 21) he first distinguishes between racial and ethnic conflict in such a way that Northern Ireland is excluded (pp. 22, 36), then returns to his 1970 definition which includes it, on the grounds that the classification of groups is at least partly subjective and that ethnic conflict is similar to race conflict. He then evades the Northern Ireland issue by limiting his study to colonial societies and those with immigrant minorities in the metropolitan countries (p 37).

There are problems in using either 'ethnicity' or 'race'. Not only does 'racism' seem inapp.ropriate in a white European context, but using the term 'race' implicitly supp.orts the dangerous (as well as unscientific) notion of genetic and therefore immutable differences between groups of people. ‘Ethnicity’ and 'ethnocentrism’ are more app.ropriate in focusing on culture and the imagined community but they also can be used to conceal the historical origins of the divisions as well as stillexisting inequalities. 
Which term is used is not, however, the main issue. Mason (1970) is among those who see commonalities in all situations of dominance and inequality, colour merely adding 'a special sharpness'. What is important is that Catholics are seen by an important section of unionists as belonging to a group which is both distinct and inferior, and that the real and potential danger posed by this group has been met with attempts at political exclusion and wide-ranging security legislation.

All the same, despite its problems, the term 'racism' seems more app.ropriate than 'ethnocentrism'. 'Racism' can exist separately from notions of race; and only the term 'racism' adequately implies the viciousness of the stereotype of the inferior group and the peculiar mixture of contempt, hatred and fear that characterises the feelings of members of the dominant (but insecure) group towards the inferior (but threatening) group. Furthermore, the Catholic Irish as a whole have been described and stigmatised as a 'race'. Given the shift from biological to cultural justifications, Fanon's term 'cultural racism’ (1967:32-3) seems the most app.ropriate.

Perhaps the most telling evidence for the continued existence of the settler mentality, however, comes from an examination of statements about Catholics by Protestants in local newspapers over the course of this century (Clayton 1995, 1996). Moderates and dissidents on the whole avoid stereotyping Catholics, focusing instead on what Protestants and respectable Catholics have in common and seeing nationalist violence as an aberration by a small minority.

The more obdurate, however, display many features of settler racism and attitudes towards the 'natives'. Settler racism has the added dimension of fear that the settlers will be dispossessed - a fear that is perfectly rational. Many Protestants see Catholics as the Other, the eternal enemy, always a threat. Not only do Catholics have no right to regain their lands, they have no right to complain. Their 'woes' are imaginary, invented by agitators and swallowed by people who cannot think for themselves. As a group Catholics are considered both inferior and dangerous. They have been accused of being lazy, dirty, devious, treacherous, violent, over-fecund, irrational, emotional, inferior in education and skills, ungrateful, easily-manipulated, superstitious, priest-dominated and in thrall to manipulative leaders. By contrast, Protestants portray themselves as hardworking and competent, independent in deed and thought, peaceful and law-abiding, but manly and resolute. All of these 
stereotypes mirror those found in other settler colonies, and constitute the 'mythical portraits' of the colonised and the coloniser described by Memmi (1990).

Details of the discourse change over time. Overt references to 'race' diminish and after the establishment of the Irish state most of the derogatory remarks refer to the 'southern Irish', until the late 1960s, with the exception of a new stereotype, that of 'dirty' Catholics 'breeding' too many children, which emerged when Protestant birth-rates noticeably fell faster than Catholics. The accusation of 'poverty' as a mark of inferiority began to lapse when Protestant poverty could no longer be overlooked. Although Protestant self-reliance continued to be asserted as a basic character trait, Northern Ireland's dependency on Britain has stifled most claims that the territory is or could be self-sufficient or independent. Nevertheless, implicit in Protestant attitudes is the assumption that Catholics will never change. The continuity of the 'mythical portrait' of Catholics allied with the consistent determination on the part of most Protestants to resist not merely rule by Catholics but even the sharing of any degree of real power with them suggests a form of racism little distinguishable from settler racism.

\section{Conclusion}

Northern Ireland is not an example of religious conflict, although doctrinal differences play an important role in defining the main opp.osing political aspirations. It is perfectly reasonable to analyse it as a plural society, with one dominant and one subordinate ethnic group. It is wholly inadequate to subtract it from its historical and global context. The parallels with settler societies illuminate the picture, although it is not claimed here that Northern Ireland's history as a settler colony explains the whole situation. No explanation which ignores this fact, however, can be complete.

8660 inc bibliography

\section{Bibliography}

Anderson, J. (1988). 'Ideological variations in Ulster during Ireland's first Home Rule crisis: an analysis of local newspapers', in C. Williams and E. Kofman, Community Conflict, Partition and Nationalism, London: Routledge, pp. 133-66

‘An Orangeman' (1799). Orange Vindicated, in a reply to Theobald McKenna Esq, with some 
observations on the new and further claims of the Catholics, as affecting the constitution and the Protestant establishment. A new edition, revised and enlarged with notes, by the author, Dublin: printed by William McKenzie

Aughey, A. (1989). Under Siege: The unionist response to the Anglo-Irish Agreement, Belfast: The Blackstaff Press

Aughey, A. (1990). 'Recent interpretations of unionism’, Political Quarterly 61(2):188-99

Aunger, E. A. (1975). 'Religion and occupational class in Northern Ireland', Economic and Social Review 7(1): 1-18

Bardon, J. (1992). A History of Ulster, Belfast: The Blackstaff Press

Bell, D. (1986). Acts of Union: Youth sub-culture and ethnic identity amongst Protestants in Northern Ireland, Paper to the Sociological Association of Ireland, Annual Conference, April 1986

Boyle, J. (1962). 'The Belfast Protestant Associations and the Independent Orange Order 1901-10', Irish Historical Studies 13:117-52

Boyle, J. F. (1977). 'Educational attainment, occupational achievement and religion in Northern Ireland', Economic and Social Review 8(2):79-100

Brady, J. (1978). ‘Pluralism and Northern Ireland', Studies 67:88-99

Brewer, J. (1992). 'Sectarianism and racism, and their parallels and differences', Ethnic and Racial Studies 15(3):352-64

Bruce, S. (1986). God Save Ulster! The religion and politics of Paisleyism, Oxford: Clarendon Press

Bruce, S. (1987). 'The Northern Ireland conflict is a religious conflict', Annual Meeting of the British Association for the Advancement of Science, Belfast, 24-28 August 1987

Buchanan, R. H. (1988). Ulster: Exploring the common ground, Canon Rogers Memorial Lecture, delivered at St Mary's College, Trench House on Tuesday 2 February 1988

Buckley, A. D. (1982). A Gentle People: A study of a peaceful community in Ulster, Cultra Manor: Ulster Folk and Transport Museum

Cahill, G. A. (1970). 'Some nineteenth century roots of the Ulster problem, 1829-1848', Irish University Review 1(2):215-37

Canny, N. (1973). 'The ideology of English colonialism: from Ireland to America', William and Mary Quarterly, 3rd Series, 30, pp. 575-598

Clayton, P. (1995). Settler Ideologies in Twentieth-Century Ulster: persistence or decline? PhD thesis, Queen's University of Belfast

Clayton, P. (1996). Enemies and Passing Friends: settler ideologies in twentieth-century Ulster, London: Pluto Press

Compton, P. A. (1976). 'Religious affiliation and demographic variability in Northern Ireland', Institute of British Geographers, Transactions 1:433-452

Crawford, R. L. (1904). Orangeism: its History and Progress. A plea for first principles, Dublin, Official Guide

Crotty, R. (1986). Ireland in Crisis, Dingle: Brandon

Cupp.les, S. (1799). Principles of the Orange Association stated and vindicated in a discourse delivered before the members of the Orange societies in Lisburn district July 12 1799, Belfast: printed by Doherty and Simms

Dewar, M. W. (1958). Why Orangeism? Belfast: Jordan

Easthope, G. (1976). 'Religious war in Northern Ireland', Sociology 10:427-50 
Fanon, F. (1965). Studies in a dying colonialism, New York: Monthly Review Press

Fanon, F. (1967). Toward the African Revolution (Political Essays), New York: Grove Press

Farrell, M. (1983). Arming the Protestants: The formation of the Ulster Special Constabulary and the Royal Ulster Constabulary, 1920-1927, London: Pluto

Gailey, A. (1987). Ireland and the Death of Kindness: The experience of constructive unionism 18901905, Cork: Cork University Press

Gibbon, P. (1972). 'The origins of the Orange Order and the United Irishmen', Economy and Society $1: 134-63$

Guelke, A. (1988). Northern Ireland: The international perspective, Dublin: Gill and Macmillan

Hartz, L. M. (1964). The Founding of New Societies: Studies in the history of the United States, Latin America, South Africa, Canada and Australia, New York: Harcourt, Brace and World, Inc.

Horowitz, D. L. (1977). 'Cultural movements and ethnic change', American Academy of Political and Social Science, Annals 433:6-18

Jackson, A. (1989). 'Unionist history (i)', The Irish Review 7:58-66

Kiernan, V. G. (1982). European Empires from Conquest to Collapse, 1850-1960, Leicester: Leicester University Press

Lecky, W. E. H (1916). A History of Ireland in the Eighteenth Century,. London: Longmans, Green and Co

Lichtheim, G. (1971). Imperialism, London: Allen Lane

Lijphart, A. (1975). 'The Northern Ireland problem: cases, theories and solutions', British Journal of Political Science 5:83-106

Long, S. E. (1972). Folders on Ulster Matters, Belfast: Belfast County Grand Orange Lodge

Long, S. E. (1978). The Orange Institution, by an Orangeman, Belfast: Grand Orange Lodge of Ireland

Lustick, I. (1985). State-Building Failure in British Ireland and French Algeria, Berkeley: University of California, Institute of International Studies

McAllister, I. (1982). 'The devil, miracles and the afterlife: the political sociology of religion in Northern Ireland', British Journal of Sociology 33(3):330-47

McAllister, I. (1983). 'Political attitudes, partisanship and social structures in Northern Ireland', Economic and Social Review 14(3): 185-200

McCartney, R. L. (1985). Liberty and Authority in Ireland, Derry: Field Day Theatre Company Limited

MacDonald, M. (1986). The Children of Wrath: Political violence in Northern Ireland, Cambridge: Polity Press

MacFarlane, A. (1978). The Origins of English Individualism, the Family, Property and Social Transition, Oxford: Basil Blackwell

McFarlane, W. G. and Graham W. (1979). 'Mixed marriages in Ballycuan, Northern Ireland', Journal of Comparative Family Studies 10(2):191-205

McKernan, J. and Russell, J. L. (1980). 'Differences of religion and sex in the value systems of Northern Ireland adolescents’, British Journal of Social and Clinical Psychology 19:115-8

Martin, J. (1982). 'The conflict in Northern Ireland: Marxist interpretations', Capital and Class 18:56-71

Mason, P. (1970). Patterns of Dominance, London: Oxford University Press 
Memmi, A. (1990). The Coloniser and the Colonised, New Introduction by L O'Dowd. London: Earthscan Publications

Moore, R. (1972). 'Race relations in the six counties: colonialism, industrialisation and stratification in Ireland', Race 14(1):21-42

Niven, R. (1899). Orangeism as it is and was. A concise history of the rise and progress of the institution, with app.endix. Also papers relating to an investigation by Royal Commission held at Castlewellan, into the occurrences at Dolly's Brae on the 12th July, 1849, Belfast: Baird

O’Dowd, L. (1990). New Introduction to A Memmi (qv) pp. 29-66

Orange Institution (1813). A Slight Sketch, with an App.endix containing the Rules and Regulations of the Orange Societies of Great Britain and Ireland, Dublin: Charles (1885) Ritual of Introduction to the Orange Order, Dublin: Forrest

Dublin: Forrest (1891) Index to principle resolutions, addresses etc. June 1881 to December 1890, (1902). Ritual of Introduction to the Orange Order, Armagh (1916). Laws and ordinances adopted December 15th 1915, Belfast: Grand Orange

Lodge of Ireland

(1963). Centenary Official History 1863-1963, Belfast: Universal Publishing Co

Osborne, R. D. (1981). 'Equality of opp.ortunity and discrimination: the case of religion in Northern Ireland', Administration 29(4):331-55

Patterson, H. (1980). 'Independent Orangeism and class conflict in Edwardian Belfast: a reinterpretation’, Royal Irish Academy 80 c(1):1-28

Patterson, H. (1982). 'Paisley and Protestant politics’, Marxism Today 26(1):26-31

Poole, M. A. (1982). 'Religious residential segregation in urban Northern Ireland', in F. W. Boal and J. N. Douglas (eds), Integration and Division: geographical perspectives on the Northern Ireland problem, London: Academic Press, pp. 281-308

Rex, J. (1986). Race and Ethnicity, Milton Keynes: Open University Press

Roberts, D. A. (1971). 'The Orange Order in Ireland: a religious institution?', British Journal of Sociology 22(3)

Robinson, P. (1982). 'Plantation and colonisation: the historical background', in F. W. Boal and J. N. H. Douglas (eds), Integration and Division: geographical perspectives on the Northern Irish problem, London: Academic Press, pp. 19-47

Rogers, E. (1881). The Revolution of 1688, and the History of the Orange Association of England and Ireland, 5th ed, Belfast: printed by W. and G. Baird

Rose, R. (1971). Governing without Consensus: an Irish perspective, London: Faber and Faber Ltd

Savage, D. C. (1960). 'The origins of the Ulster Unionist Party 1885-6', Irish Historical Studies 12:185-208

Schutz, B. M. and Scott, D. (1975). 'Natives and settlers - comparative analysis of the politics of opp.osition and mobilisation in Northern Ireland and Rhodesia', Monograph, Series in World Affairs 12 (M2):1-67

Singleton, D. (1982). 'Housing a divided community: the paradox of reform in Northern Ireland', Housing Review 31(3):77-81

Sinnott, R. and Davis, E. E. (1981). 'Political mobilisation, political institutionalisation and the maintenance of ethnic conflict’, Ethnic and Racial Studies 4(4):398-414 
Smith, A. D. S. (1981). The Ethnic Revival in the Modern World, Cambridge: Cambridge University Press

Smith, A. D. S. (1986). The Ethnic Origins of Nations, Oxford: Blackwell

Smyth, M. (1972). Battle for Northern Ireland, Belfast: Belfast County Grand Orange Lodge

Stringer, P. and Robinson, G (1991). Social Attitudes in Northern Ireland, Belfast: Blackstaff

Todd, J. (1987). ‘Two traditions in unionist political culture’, Irish Political Studies 2:1-26

'Veritas' (1814). Letters written in England, in August 1813, explaining the Rise, Progress and Principles of the Orange Institution, in Ireland. With additional notes, Dublin: Tute

Walker, B. (1990). 'Ireland's historical position - “Colonial” or “European”?’, The Irish Review 9:3640

Wallerstein, I. (1980). The Modern World-System II: Mercantilism and the consolidation of the European world-economy, 1600-1750, New York: Academic Press

Wallis, R., Bruce, S. and Taylor, D. (1986). 'No Surrender': Paisleyism and the politics of ethnic identity in Northern Ireland,. Belfast: Department of Social Studies, Queen’s University of Belfast

Weber, M. (1930). The Protestant Ethic and the Spirit of Capitalism (translated by Talcott Parsons), London: Allen and Unwin. First published in German in 1904.

Weitzer, R. J. (1990). Transforming Settler States: communal conflict and internal security in Northern Ireland and Zimbabwe, Berkeley: University of California Press

Whyte, J. H. (1990). Interpreting Northern Ireland. Oxford: Clarendon Press

Wright, F. (1973). 'Protestant ideology and politics in Ulster', Archives Européennes de Sociologie 14:213-80

Wright, F. (1987). Northern Ireland: a comparative analysis, Dublin: Gill and Macmillan

Wright, F. (1990). ‘Is Northern Ireland Britain’s Algeria?’ De Gaulle et son siècle, Journées Internationales, paper F086, 19-24 November. Paris: UNESCO 